\title{
De doorstroom van Limburgse basisartsen naar medische beroepsopleidingen
}

Citation for published version (APA):

Borghans, L., \& Ramaekers, G. W. M. (1993). De doorstroom van Limburgse basisartsen naar medische beroepsopleidingen. Researchcentrum voor Onderwijs en Arbeidsmarkt, Faculteit der Economische Wetenschappen. ROA Working Papers No. 1 https://doi.org/10.26481/umarow.1993001

Document status and date:

Published: 01/01/1993

DOI:

10.26481/umarow.1993001

Document Version:

Publisher's PDF, also known as Version of record

\section{Please check the document version of this publication:}

- A submitted manuscript is the version of the article upon submission and before peer-review. There can be important differences between the submitted version and the official published version of record.

People interested in the research are advised to contact the author for the final version of the publication, or visit the DOI to the publisher's website.

- The final author version and the galley proof are versions of the publication after peer review.

- The final published version features the final layout of the paper including the volume, issue and page numbers.

Link to publication

\footnotetext{
General rights rights.

- You may freely distribute the URL identifying the publication in the public portal. please follow below link for the End User Agreement:

www.umlib.nl/taverne-license

Take down policy

If you believe that this document breaches copyright please contact us at:

repository@maastrichtuniversity.nl

providing details and we will investigate your claim.
}

Copyright and moral rights for the publications made accessible in the public portal are retained by the authors and/or other copyright owners and it is a condition of accessing publications that users recognise and abide by the legal requirements associated with these

- Users may download and print one copy of any publication from the public portal for the purpose of private study or research.

- You may not further distribute the material or use it for any profit-making activity or commercial gain

If the publication is distributed under the terms of Article $25 \mathrm{fa}$ of the Dutch Copyright Act, indicated by the "Taverne" license above, 


\title{
DE DOORSTROOM VAN LIMBURGSE BASISARTSEN
}

NAAR MEDISCHE BEROEPSOPLEIDINGEN

\author{
ROA-W-1993/1
}

L. Borghans en G.W.M. Ramaekers

RESEARCHCENTRUM VOOR ONDERWIJS EN ARBEIDSMARKT

Faculteit der Economische Wetenschappen

Rijksuniversiteit Limburg

Maastricht, september 1993 


\section{CIP-GEGEVENS KONINKLIJKE BIBLIOTHEEK, DEN HAAG}

\section{Borghans, L.}

De doorstroom van Limburgse basisartsen naar medische beroepsopleidingen / L. Borghans en G.W.M. Ramaekers. - Maastricht : Researchcentrum voor Onderwijs en Arbeidsmarkt, Faculteit der Economische Wetenschappen, Rijksuniversiteit Limburg. - ([Werkdocument] Researchcentrum voor Onderwijs en Arbeidsmarkt, ISSN 0922-4645 ; ROA-W-1993/1) ISBN 90-5321-113-6

Trefw.: arbeidsmarkt ; artsen ; Limburg. 


\section{INHOUDSOPGAVE}

$\begin{array}{ll}\text { 1. INLEIDING } & 1\end{array}$

2. OPZET VAN DE ARBEIDSMARKTSCANNER RL 5

3. $\quad$ KANS DAT MEN EEN OPLEIDINGSPLAATS AMBIEERT 7

4. KANS DAT MEN EEN OPLEIDINGSPLAATS VINDT 11

$\begin{array}{ll}\text { 5. INKOMEN } & 14\end{array}$

6. SCHETS VAN DE MARKT VOOR MEDISCHE OPLEIDINGSPLAATSEN 19

$\begin{array}{ll}\text { LITERATUUR } & 21\end{array}$

BIJLAGE 1. DEFINITIE VAN VARIABELEN IN DE SCHATTINGEN 22

BIJLAGE 2. BEREKENING VAN HET INKOMEN 25

BIJLAGE 3. SCHATTINGSRESULTATEN VAN HET INKOMEN 26 


\section{INLEIDING}

De geneeskunde heeft tussen de academische opleidingen altijd een bijzondere plaats ingenomen. De instroom wordt al sinds vele jaren bepaald door een numerus fixus. Verder is door de opsplitsing in doctoraal en co-assistentschappen de opleiding tot basisarts een van de weinige academische opleidingen die formeel langer dan vier jaar duurt. $\mathrm{Na}$ deze toch al langdurige opleiding zijn voor het uitoefenen van een aantal medische beroepen nog additionele opleidingen verplicht, die gevolgd kunnen worden in een opleidingsplaats.

Het bijzondere karakter van deze opleiding blijft echter niet beperkt tot de opleidingstijd zelf. Aan de Rijksuniversiteit Limburg (RL) wordt sinds 1990 onderzoek gedaan naar de arbeidsmarktpositie van afgestudeerden. Uit dit onderzoek blijkt onder meer dat van de afgestudeerden van de RL (te weten basisartsen, gezondheidswetenschappers, juristen en economen) medici en economen de kortste intrede-werkloosheidsduur hebben. Verder zijn de Iōnen die afgestudeerde basisartsen verdienen aanmerkelijk hoger dan die van hun collega's van andere faculteiten. Ondanks deze gunstige arbeidsmarktpositie blijken veel betaald werkende basisartsen toch niet bijzonder tevreden over hun positie op de arbeidsmarkt. Vergeleken met de andere opleidingen blijkt een veel groter deel van de betaald werkenden namelijk op zoek te zijn naar een andere baan'.

Deze ontevredenheid onder afgestudeerde medici wordt waarschijnlijk voor een groot deel veroorzaakt door een gebrek aan opleidingsplaatsen. In principe zijn er drie soorten banen waarin medici terecht komen. Allereerst wordt een aantal basisartsen Assistent In Opleiding (AIO) of Onderzoeker In Opleiding (OIO). Daarnaast vindt een aantal basisartsen een opleidingsplaats, waarbij werk gecombineerd wordt met een opleiding voor een medisch beroep. Dit betreft sociaal-geneeskundigen in opleiding, huisartsen in opleiding en specialisten in opleiding (Assistent Geneeskundigen In Opleiding, ofwel AGIO's). De sociaal-geneeskundigen volgen naast hun baan een opleiding, terwijl de huisartsen en de specialisten in opleiding een speciale opleidingsplaats hebben waar zij het vak 'on the job' leren. Tenslotte is een aantal basisartsen werkzaam als assistent geneeskundige, maar niet in opleiding (Assistent Geneeskundigen Niet In Opleiding, ofwel AGNIO's) of is werkzaam in een ander beroep dat geen opleidingskarakter heeft. Alleen het werk van de tweede groep, sociaal-geneeskundigen, huisartsen, en specialisten in opleiding, wordt aangeduid met de term opleidingsplaats. Voor veel medische professies is het succesvol afronden van zo'n opleidingsplaats een wettelijke vereiste (civiel effect). En terwijl de arbeidsmarkt voor basisartsen redelijk in evenwicht lijkt te zijn, bekeken vanuit de vraag of de afgestudeerde artsen al dan niet een - goed betaalde baan weten te vinden, is de mate waarin basisartsen er in slagen een opleidingsplaats te krijgen ongebalanceerd. Een grote groep afgestudeerden zoekt nog een opleidingsplaats, terwijl er slechts een beperkt aantal plaatsen beschikbaar is.

Op zich is het niet bijzonder dat slechts een kleine groep afgestudeerden in bepaalde, typisch bij

1. Zie Ramaekers en Heijke (1991) ROA-W-1993/1. 
het vak horende specialismen terecht komt. Op grond van de economische theorie zou men echter mogen verwachten dat dergelijke bijzondere opleidingsbanen, ofwel toegedeeld zouden worden aan de personen met grotere capaciteiten op het betreffende gebied, ofwel dat de aantrekkelijkheid van de opleidingsplaats, in negatieve zin, gecompenseerd wordt in het financiële vlak. Dat wil dus zeggen dat opleidingsplaatsen een lager loon kennen, zodat het animo voor dergelijke beroepen met een opleidingskarakter kleiner zal zijn².

Bij basisartsen lijken echter beide selectiemechanismen niet volledig te werken, gezien de opvallend grote mate van zoekgedrag. Indien er geselecteerd zou worden op objectief waarneembare capaciteiten, dan is het voor afgestudeerden waarschijnlijk redelijk goed mogelijk de eigen kansen op een opleidingsplaats in te schatten. Een grote groep basisartsen zou dan bij voorbaat al weten dat de kansen op een dergelijke plaats niet groot zijn, en zal zich derhalve de moeite van het zoeken besparen. Alleen een kleine groep afgestudeerden, voor wie het nog onduidelijk is of hun capaciteiten hoog genoeg zijn, zullen nog enige tijd volharden in het zoekgedrag om na enige tijd, ofwel alsnog een plaats te vinden, ofwel alsnog tot het inzicht te komen dat verder zoeken geen zin heeft.

Ook als de aantrekkelijkheid van opleidingsplaatsen in voldoende mate gereguleerd zou worden met behulp van loondifferentiatie, zou er geen hoge mate van zoekgedrag te verwachten zijn. Voor iedere afgestudeerde geldt dan immers dat hij een afweging moet maken tussen de (toekomstige) voordelen van de opleidingsplaats en de bijbehorende tijdelijke financiële nadelen. Als deze afweging echter wordt gemaakt, zou, als de loon-compensatie de juiste omvang heeft, een voldoende grote groep moeten afzien van een opleidingsplaats zodat voor de overblijvende groep de kans op het vinden van een plaats redelijk groot zou moeten zijn.

Op grond van deze gedachtengang is de grote hoeveelheid zoekers op de markt van medici merkwaardig. Het lijkt er dan ook op dat de allocatie van artsen over de beschikbare banen opleidingsplaatsen versus niet-opleidingsplaatsen - op twee fronten afwijkt van het reguliere patroon. In de eerste plaats lijkt de selectie van afgestudeerden voor de opleidingsplaatsen in grote mate een arbitrair karakter te hebben. De afgestudeerden zijn kennelijk onvoldoende in staat om zelf hun capaciteiten (en daarmee hun kansen) in te schatten, hetgeen een voorwaarde is voor zelfselectie. Daarnaast lijken opleidingsplaatsen - in ieder geval voor een grote groep basisartsen - onevenredig aantrekkelijk te zijn vergeleken met andere banen in de medische wereld. Als de aantrekkelijkheid van beide typen banen meer in onderlinge overeenstemming zou zijn, dan zouden de basisartsen niet bereid zijn een zo hoge zoekinspanning te verrichten voor het verkrijgen van een opleidingsplaats. Dit duidt opnieuw op het bijzonder karakter van de artsenloopbaan. Niet alleen hebben aankomende artsen vóor het begin van hun studie moeten loten voor het recht op deelname, maar ook wanneer zij reeds basisarts zijn, moeten zij opnieuw 'loten', maar dit keer voor een opleidingsplaats.

2. Zie bijvoorbeeld Hartog (1992). 
Figuur 1. Limburgse basisartsen op de arbeidsmarkt

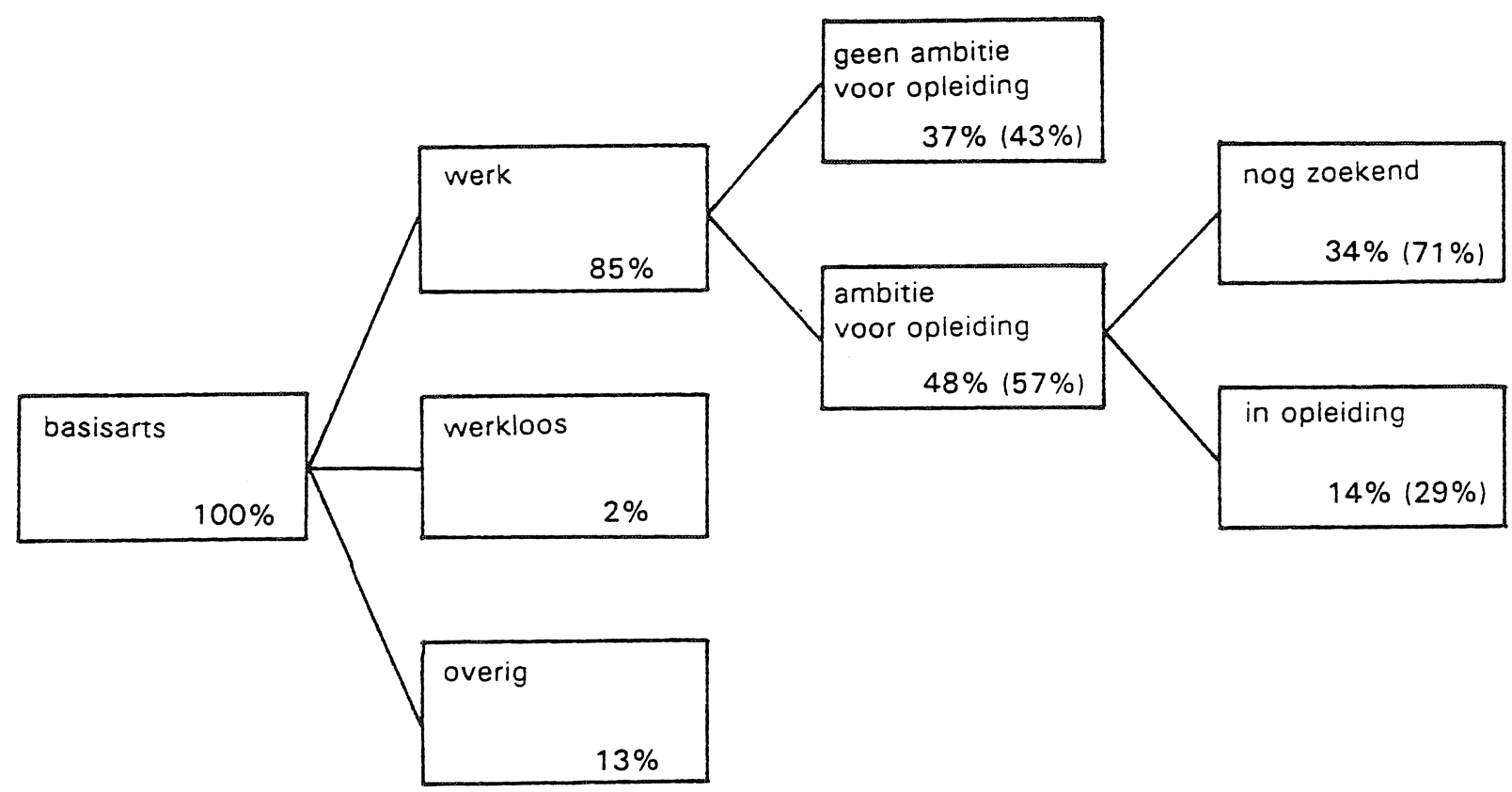

In dit paper wordt het allocatieproces op de arbeidsmarkt voor basisartsen nader empirisch geanalyseerd. Dit gebeurt aan de hand van de resultaten uit de Arbeidsmarktscanner RL, de al eerder genoemde periodieke enquête onder alumni van de Rijksuniversiteit Limburg. Hierbij wordt aan alle afgestudeerden jaarlijks, te beginnen ongeveer én jaar na afstuderen, een vragenlijst voorgelegd over hun positie op de arbeidsmarkt. In paragraaf 2 wordt deze schoolverlatersenquête nader toegelicht. De analyse van de arbeidsmarktpositie van basisartsen in dit paper vindt plaats op basis van het stroomschema in figuur 1. Een kleine groep basisartsen $(2 \%)$ heeft circa een jaar na het afstuderen nog geen betaald werk. Deze groep is echter dermate klein dat een statistische analyse weinig zinvol is. De analyse beperkt zich daarom tot degenen die wel werk hebben gevonden. Gezien vanuit de hierboven geschetste problematiek van een tekort aan opleidingsplaatsen zijn drie interessante groepen te onderscheiden. Ten eerste kunnen de werkende basisartsen verdeeld worden in een groep die een opleidingsplaats ambieert $(57 \%)$ en een groep die een dergelijke plaats niet ambieert $(43 \%)$. Het onderscheid tussen deze twee groepen komt aan de orde in paragraaf 3. Van hen die wel een opleidingsplaats ambiëren, is slechts een klein gedeelte er na een jaar in geslaagd om een dergelijke plaats te bemachtigen (29\%), terwijl de meesten $(71 \%)$ dan nog steeds op zoek zijn naar een opleidingsplaats. In paragraaf 4 komt de vraag aan de orde welke factoren de kans bepalen dat iemand (binnen ongeveer éen jaar) een opleidingsplaats weet te vinden. Deze 
$-4-$

analyse van de verdeling van basisartsen over de drie groepen kan inzicht geven in de allocatieen selectieprocessen op de arbeidsmarkt van basisartsen.

Er worden dus, afgezien van de degenen die geen betaald werk verrichten, drie groepen onderscheiden. Ten eerste is er een groep basisartsen die geen opleidingsplaats ambiëren. De groep die wel een opleidingsplaats ambieert, is opgedeeld in twee subgroepen: een groep ambitieuzen die nog op zoek zijn naar een opleidingsplaats en een groep ambitieuzen die reeds een opleidingsplaats hebben gevonden. In paragraaf 5 wordt gekeken hoe de beloningen in deze drie groepen zijn opgebouwd. Op grond hiervan kan bekeken worden in hoeverre er sprake is van looncompensaties voor (on)aantrekkelijk werk, en welke kosten er verbonden zijn aan het zoeken van een opleidingsplaats.

Tenslotte worden in paragraaf 6 de empirische bevindingen op een rijtje gezet en wordt, in concluderende termen, een algemene kenschets gemaakt van de markt van de afgestudeerde basisartsen. 


\section{OPZET VAN DE ARBEIDSMARKTSCANNER RL}

De RL is de jongste universiteit van Nederland. De instelling bestaat uit vijf faculteiten: geneeskunde, gezondheidswetenschappen, rechtsgeleerdheid, economische wetenschappen en algemene wetenschappen. Het onderwijs aan de Faculteit der Geneeskunde (FdG) is gestart in september 1974. Het onderwijs is sterk geënt op actuele ontwikkelingen binnen de gezondheidszorg. Het accent ligt op de eerstelijns gezondheidszorg. Evenals bij andere medische faculteiten het geval is, volgen de studenten eerst de vierjarige opleiding tot het doctoraalexamen en vervolgens de tweejarige opleiding tot basisarts. De opleiding kan worden voortgezet in een post-basisartsopleiding voor huisarts, sociaal-geneeskundige of medisch specialist, dan wel in een opleiding voor onderzoeker. Tot de eerste-fase opleiding geneeskunde in Limburg worden jaarlijks maximaal 150 studenten toegelaten.

Sinds 1990 wordt er aan de RL jaarlijks onderzoek gedaan onder de afgestudeerden van deze universiteit. Dit onderzoeksproject wordt genoemd 'Arbeidsmarktscanner RL'. De arbeidsmarktscanner bestaat uit twee instrumenten. Het eerste instrument betreft de basisvragenlijst. Hiermee worden alle oud-studenten éen tot anderhalf jaar na het afstuderen schriftelijk geënquêteerd (de basismeting). Er wordt gevraagd naar de volgende kerngegevens:

- persoonsgegevens (geslacht en leeftijd);

- de aan de RL afgesloten opleiding (studie/afstudeerrichting en maand van afstuderen);

- de hoogst voltooide vooropleiding (niveau en indien van toepassing richting);

- werkervaring en bestuurlijke ervaring tot het afstuderen;

- of men na het afstuderen additioneel onderwijs volgt (niveau en richting);

- de maatschappelijke positie, per maand gemeten, vanaf de maand van afstuderen tot en met de maand van enquêteren;

- kenmerken van de functie (wijze waarop men de functie heeft gevonden, dienstverband, soort aanstelling, wekelijkse arbeidsduur, beroep, voor de functie vereiste opleiding, leidinggeven en inkomen);

- kenmerken van de werkorganisatie (branche, organisatiegrootte en lokatie);

- of men op zoek is naar (ander) betaald werk.

Het tweede instrument is de loopbaanvragenlijst. Dit vragenformulier wordt meerjaarlijks toegestuurd als een vervolg op de basisvragenlijst. De loopbaanvragenlijst is een verkorte versie van de basisvragenlijst. Met behulp van het desbetreffende formulier kan de respondent eventuele wijzigingen doorgeven die sinds de basismeting in zijn arbeidssituatie zijn opgetreden, bijvoorbeeld het veranderen van baan. Jaarlijks vinden dus twee enquêtes plaats: de basismeting onder de afgestudeerden van het voorgaande jaar en de loopbaanmeting onder oudstudenten die daaraan voorafgaand zijn afgestudeerd.

In dit paper worden de resultaten gepresenteerd van het onderzoek met behulp van de basisvragenlijst naar de arbeidsmarktpositie die basisartsen circa een jaar na het afstuderen innemen. Het gaat hierbij om in totaal 418 basisartsen die in de periode juli 1988 tot en met december 1991 in Maastricht zijn afgestudeerd. Hiervan hebben er 345 aan het onderzoek 
$-6-$

meegewerkt, hetgeen neerkomt op een alleszins bevredigende respons van $83 \%$. Vanwege het nog kleine aantal respondenten, wordt er in dit paper geen gebruik gemaakt van gegevens uit de loopbaanvragenlijst. 


\section{KANS DAT MEN EEN OPLEIDINGSPLAATS AMBIEERT}

Zoals in de inleiding reeds werd beschreven, is het op de arbeidsmarkt van basisartsen niet eenvoudig om een opleidingsplaats te bemachtigen. De eerste keuze die een afgestudeerde basisarts op weg naar een opleidingsplaats echter moet maken, is de vraag of hij überhaupt wel wil meedingen naar een opleidingsplaats. Er zijn immers ook andere functies die een afgestudeerde basisarts kan vervullen, en het is dus niet vanzelfsprekend dat hij zonder meer tot medisch specialist wil doorgroeien.

In deze paragraaf wordt gekeken naar de ambitie die basisartsen hebben om in een opleidingsplaats te komen, en naar de factoren die hierbij een rol spelen. Daartoe is het allereerst noodzakelijk om te bepalen welke basisartsen deze ambitie hebben. Aangezien in de enquête bij afstudeercohort '88 en '89 nog niet rechtstreeks gevraagd werd naar de toekomstplannen, is gekozen voor een indirecte benadering van dit probleem. Uitgangspunt hierbij is de veronderstelling dat iedereen die werk heeft, maar toch nog op zoek is naar een andere baan, dit doet omdat hij op zoek is naar een opleidingsplaats. Uiteraard kan het ook zo zijn dat iemand die niet de ambitie heeft om sociaal-geneeskundige, huisarts of medisch specialist te worden toch ontevreden is met zijn huidige functie en verder zoekt. Echter, in de context van de medische wereld, waarin de medische beroepsopleiding een zeer belangrijke plaats inneemt, lijkt de bovengenoemde veronderstelling alleszins redelijk. Dit wordt bevestigd door de enquête van Van Hoof et al. (1992), waaruit blijkt dat de eerste voorkeur van bijna alle basisartsen uitgaat naar een of andere opleidingsplaats. In het onderzoek onder Limburgse basisartsen is voor het eerst bij afstudeercohort ' 90 gevraagd naar het soort baan dat men zoekt. Gebleken is dat inderdaad de overgrote meerderheid $(86 \%)$ van de betaald werkende basisartsen die geen opleidingsplaats hebben, en een andere baan zoeken, op zoek zijn naar een opleidingsplaats.

Naast de categorie werkzoekenden hebben uiteraard ook degenen die reeds een opleidingsplaats hebben verworven de ambitie een dergelijke opleiding te volgen. Gezien de moeilijkheid een opleidingsplaats te verwerven, lijkt het vrijwel uitgesloten dat er basisartsen zijn die een opleidingsplaats aanvaarden, hoewel ze eigenlijk op zoek zijn naar een ander soort baan. Wel kan iemand die een opleidingsplaats heeft verder zoeken naar een, in zijn ogen, betere opleidingsplaats. Dit maakt echter voor de vraag of hij al dan niet specialistische ambities heeft niets uit. In de verdere analyse wordt er dus van uitgegaan dat iedere werkende basisarts een opleidingsplaats ambieert, die hetzij op zoek is naar een andere baan hetzij reeds in een opleidingsplaats werkzaam is.

Als een afgestudeerde basisarts moet beslissen of hij al dan niet op zoek zal gaan naar een opleidingsplaats, zal deze beslissing theoretisch gezien afhangen van een aantal factoren. Deze factoren zijn weergegeven in figuur 2. De eerste factor betreft zijn persoonlijke waardering voor het werk als specialist, huisarts, of sociaal-geneeskundige, vergeleken met een loopbaan waarvoor de opleiding tot een van deze beroepen niet nodig is. Hierbij kunnen zowel persoonlijke voorkeuren als het loon een rol spelen. Een basisarts krijgt echter niet automatisch 
een opleidingsplaats. Hij zal moeten solliciteren en heeft slechts een kans zo'n plaats te krijgen, geen zekerheid. Aan het zoekgedrag zijn echter wel kosten verbonden. Hierbij kan gedacht worden aan directe kosten, verbonden aan het solliciteren. Belangrijker echter zijn de kosten die gemaakt worden doordat men gedurende de periode dat men serieus op zoek is naar een opleidingsplaats, andere beslissingen op de arbeidsmarkt zal nemen dan wanneer men niet mee zou dingen naar een opleidingsplaats.

Figuur 2. Ambitie als de afweging tussen de voordelen van een opleidingsplaats en de kosten van het zoeken

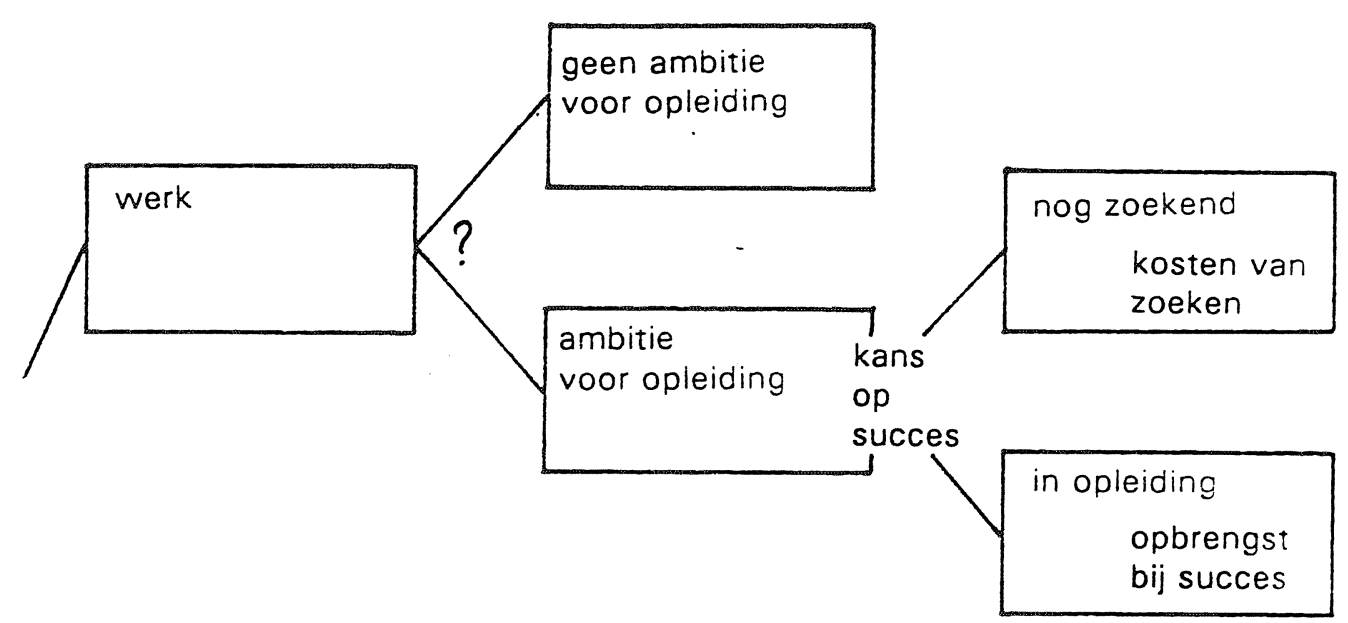

Een dergelijke afweging tussen de voordelen van een opleidingsplaats en de kosten van het zoeken en/of mislukken wordt in de literatuur zelfselectie genoemd (Willis en Rosen, 1979, en Goddeeris, 1988). Degenen die een opleidingsplaats ambiëren, hebben hun eigen kansen ingeschat en op grond daarvan zichzelf voorgeselecteerd voor een opleidingsplaats.

Als een basisarts reeds vooraf zou weten dat hij niet in aanmerking komt voor een opleidingsplaats, zou hij keuzen op de arbeidsmarkt maken die voor zijn carrière buiten de medische specialismen optimaal zijn. Afhankelijk van zijn voorkeur zou hij zich bijvoorbeeld kunnen richten op een hoog inkomen of een prettige werksfeer binnen dit alternatieve beroepsdomein. Als een basisarts echter nog steeds een opleidingsplaats ambieert, zal hij doorgaans kiezen voor banen - samen met eventueel cursussen of nevenactiviteiten - die speciaal gericht zijn op het vergroten van zijn kansen op een opleidingsplaats. Zo wordt een aantal basisartsen AIO of AGNIO om de kans op het verkrijgen van een opleidingsplaats zo groot mogelijk te maken. Als het zoeken van een opleidingsplaats evenwel mislukt, dan zal deze 
achterstand weer ingehaald moeten worden. Dat zijn de kosten bij mislukt zoekgedrag. Als men na verloop van tijd een opleidingsplaats vindt, dan zijn de kosten van het geslaagde zoekgedrag dus afhankelijk van de periode dat men heeft moeten zoeken.

In een optimale afweging van de voor- en nadelen van het al dan niet zoeken van een opleidingsplaats zullen de individuele kansen en de kosten van het zoeken worden afgewogen tegen de voordelen van een opleidingsplaats. Basisartsen met een relatief lage voorkeur voor een opleidingsplaats zullen niet snel de ambitie tonen om een dergelijke plaats te verwerven. Ook basisartsen die hun kans op het verwerven van een opleidingsplaats laag inschatten - of die denken dat ze er erg veel voor moeten doen of er erg lang naar zullen moeten zoeken, waardoor de kosten van het zoeken hoog worden - zullen snel de neiging hebben af te zien van het zoeken van een opleidingsplaats ${ }^{3}$.

De kans op het verwerven van een opleidingsplaats kan afhangen van persoonlijke eigenschappen, maar kan ook bepaald worden door de arbeidsmarktsituatie op het moment van afstuderen. Als er op het moment van afstuderen relatief veel vraag is naar gegadigden voor deze opleidingsplaatsen zijn de kansen groter en zullen - voor zover de keuzen bepaald worden door de kansen - meer artsen op zoek gaan naar een opleidingsplaats.

Tabel 1. Resultaten logit-schatting van de ambitie voor een opleidingsplaats

\begin{tabular}{lccc}
\hline & $\begin{array}{c}\text { regressie } \\
\text { coëfficiënt }\end{array}$ & standaard-fout & significantie \\
\hline & $-0,24$ & 0,27 & 0,37 \\
geslacht & $0,12^{*}$ & 0,06 & 0,05 \\
leeftijd & $-0,79$ & 0,51 & 0,12 \\
HO-vooropleiding & 0,20 & 0,30 & 0,50 \\
studentassistentschap & $-0,65 *$ & 0,36 & 0,33 \\
medische werkervaring & 0,33 & 0,34 & 0,68 \\
niet-medische werkervaring & 0,11 & 0,27 & 0,16 \\
bestuurlijke ervaring & 0,05 & 0,03 & 0,93 \\
zoektijd (in maanden) & $-0,04$ & 0,40 & 0,31 \\
cohort 89 & 0,41 & 0,40 & 0,75 \\
cohort 90 & $-0,12$ & 0,39 & 1,66 \\
cohort 91 & $-3,56$ & & \\
constante & & & \\
\hline
\end{tabular}

* $\quad$ significant op $10 \%$ niveau

* * significant op $5 \%$ niveau

* * significant op $1 \%$ niveau

In tabel 1 staan de resultaten van een logit-schatting van de kans dat een werkende basisarts ambities heeft voor een opleidingsplaats.

3. Zie ook Manski (1989). 
De gemeten samenhang tussen de verklarende variabelen die in de analyse konden worden meegenomen en de ambitie-variabele is niet erg hoog. Slecht twee variabelen, buiten de constante, zijn significant op $10 \%$ niveau. De leeftijd van de basisarts heeft een positieve invloed op de kans dat hij de ambitie heeft een medische opleidingsplaats te verwerven, dit wil zeggen dat oudere afgestudeerden meer genegen zijn om een opleidingsplaats te zoeken. Werkervaring op medisch gebied, opgedaan vóór of tijdens de studie aan de RL heeft een negatieve invloed op deze ambitie. Bekend maakt hier wellicht onbemind. Geslacht en extra kwalificaties in de vorm van een eerder voltooide hogere beroeps- of universitaire opleiding, student-assistentschappen, bestuurlijke ervaring en niet aan medisch werk gerelateerde werkervaring, opgedaan voor of tijdens de studie lijken geen invloed te hebben. Van het geslacht wordt vaak aangenomen dat het een zeer belangrijke factor is in de carrière van basisartsen. In deze analyse kan geen significant effect van het geslacht worden geconstateerd. Ook is het opvallend dat de ervaringsvariabelen, die een aanduiding kunnen zijn van extra capaciteiten waarover men beschikt, weinig invloed hebben op de ambitie. Kennelijk spelen human-capital-argumenten geen rol van betekenis bij de keuze om een post-basisartsopleiding te gaan volgen. Dat de tijd die men reeds is afgestudeerd geen invloed heeft, ligt voor de hand omdat de beslissing om wel of niet te gaan zoeken naar een opleidingsplaats doorgaans een beslissing voor langere tijd is, die niet binnen een jaar herroepen zal worden. Verder hebben de dummy's voor de cohorten - waarbij 1988 als referentie dient - geen significante invloed op de ambitie ${ }^{4}$. Deze dummy's zijn opgenomen om de effecten van de arbeidsmarktsituatie voor medici op de ambitie na te kunnen gaan. Als de arbeidsmarktsituatie slecht is, dit wil zeggen als er relatief weinig opleidingsplaatsen voorhanden zijn, zullen basisartsen ook hun kansen op het verkrijgen van een opleidingsplaats laag inschatten. Als deze kansen belangrijk zijn voor hun ambitie zou derhalve in voor medici slechte tijden een negatieve invloed van de cohortdummy op de ambitie moeten bestaan.

Op grond van deze analyse kan niet geconcludeerd worden welke jaren gunstig waren voor het verwerven van een opleidingsplaats. In de volgende paragraaf zal de kans op het daadwerkelijk vinden van een dergelijke plaats geschat worden, waarbij wordt nagegaan hoe deze kansen verdeeld zijn over de tijd.

4. Bij de cohortdummy's wordt in de tabel alleen de significantie van het verschil met het referentiejaar 1988 aangegeven. De overige onderlinge verschillen zijn echter ook niet significant. 


\section{KANS DAT MEN EEN OPLEIDINGSPLAATS VINDT}

Van degenen die besloten hebben op zoek te gaan naar een opleidingsplaats, slaagt slechts een klein gedeelte er in om binnen de enquête-tijd van een tot anderhalf jaar een dergelijke plaats te vinden. In deze paragraaf komt de vraag aan de orde of er duidelijke factoren zijn aan te wijzen die de kans op het vinden van een opleidingsplaats bevorderen. In tabel 2 staan de resultaten van een logit-schatting die het vinden van een opleidingsplaats poogt te verklaren uit persoonlijke en omgevingsvariabelen. Deze regressie is uitgevoerd voor de groep basisartsen die een opleidingsplaats ambiëren, zoals gedefinieerd in de vorige paragraaf. Deze groep is vervolgens opgesplitst in een groep nog zoekende basisartsen en een groep die reeds een opleidingsplaats heeft gevonden. Bij deze indeling doet zich het probleem voor dat er enkele basisartsen zijn die ander werk zoeken, hoewel ze reeds een opleidingsplaats hebben. Kennelijk zijn zij niet tevreden met de door hen gevonden plaats en zoeken zij verder. In de analyse zijn deze basisartsen ingedeeld in de groep die reeds een specialisatie gevonden hebben, hoewel het ook verdedigbaar is ze in te delen bij de artsen die nog zoeken. Het blijkt echter dat de gepresenteerde resultaten nauwelijks gevoelig zijn voor deze verandering van definitie.

Tabel 2. Resultaten logit-schatting van het realiseren van een opleidingsplaats

\begin{tabular}{lccc}
\hline & $\begin{array}{c}\text { regressie } \\
\text { coëfficiënt }\end{array}$ & standaard-fout & significantie \\
\hline & & & 0,24 \\
geslacht & 0,47 & 0,40 & 0,91 \\
leeftijd & 0,01 & 0,07 & 0,86 \\
HO-vooropleiding & $-0,14$ & 0,76 & 0,12 \\
studentassistentschap & 0,64 & 0,42 & 0,99 \\
medische werkervaring & $-0,01$ & 0,60 & 0,24 \\
niet-medische werkervaring & 0,54 & 0,46 & 0,71 \\
bestuurlijke ervaring & $-0,15$ & 0,40 & 0,32 \\
zoektijd (in maanden) & 0,05 & 0,05 & 0,04 \\
cohort 89 & $1,79 *$ & 0,86 & 0,06 \\
cohort 90 & $1,57 *$ & 0,85 & 0,01 \\
cohort 91 & $2,18 * *$ & 0,83 & 2,27 \\
constante & $-4,08$ & & \\
\hline
\end{tabular}

* $\quad$ significant op $10 \%$ niveau

* significant op $5 \%$ niveau

*** significant op $1 \%$ niveau

Van de variabelen die informatie geven over de eigenschappen van de persoon is geen enkele significant. Dit is opmerkelijk omdat dit erop schijnt te wijzen dat niet alleen het geslacht, maar ook extra kwalificaties als relevante werkervaring en bestuurlijke ervaring geen wezenlijke invloed hebben op de kans om een opleidingsplaats te bemachtigen. Alleen een studentassistentschap tijdens de studie lijkt nog enige invloed op deze kans te hebben. Dit kan uiteraard niet alleen komen door de ervaring opgedaan tijdens dit assistentschap (human capital argument), maar ook door de contacten die hierdoor gelegd zijn met medisch specialisten (screeningargument). De lage samenhang tussen de persoonskenmerken en het verkrijgen van 
een opleidingsplaats zou er op kunnen wijzen dat in de medische vakdeelmarkt selectie niet primair geschiedt op basis van het beschikbare human capital, maar dat het basisartsendiploma op zich de belangrijkste factor is, conform de credential-theorie van Collins (1979). De toebedeling van opleidingsplaatsen aan de basisartsen zou dan zelf vrij arbitrair zijn. Het is echter ook mogelijk dat de verdeling van opleidingsplaatsen onder basisartsen vooral geschiedt op basis van minder objectieve kenmerken, zoals de persoonlijke indruk die men maakt of de inschatting van iemands vermogen om onder hoge werkdruk te kunnen functioneren. De selectie zou dan niet willekeurig zijn, maar moeilijk gevangen kunnen worden in de objectieve variabelen uit de enquête. De grote groep basisartsen die toch nog zoekt naar een opleidingsplaats duidt er echter op dat de basisartsen zelf kennelijk ook niet goed in staat zijn deze kansbepalende factoren in te schatten. Hieruit kan afgeleid worden dat aan de wijze waarop basisartsen geselecteerd worden voor de opleidingsplaatsen, geen duidelijk herkenbare criteria ten grondslag liggen. Het aantal beschikbare plaatsen bepaalt in hoge mate de individuele kans op een opleidingsplaats. Gezien de grote zoekinspanningen die basisartsen verrichten om een opleidingsplaats te bemachtigen, is dit a-selecte selectiesysteem niet alleen minder efficiënt omdat het niet leidt tot een optimale allocatie van talent, maar ook minder efficiënt omdat het aanleiding geeft tot zoekstrategieën die vanuit het individuele perspectief wel optimaal zijn, maar die maatschappelijk een grote verspilling van tijd en moeite zijn.

De variabelen die een bijzonder grote invloed op de kans op het verkrijgen van een opleidingsplaats hebben, zijn de cohort-dummy's $s^{5}$. Alle cohort-dummy's zijn significant (t.o.v. 1988) en ook de parameterwaarden zijn behoorlijk groot. De kansen om een opleidingsplaats te verwerven zijn volgens deze schattingen behoorlijk gestegen van 1988 tot 1991 . De schattingen impliceren dat de kans om binnen een jaar een opleidingsplaats te krijgen in 1991 ongeveer drie maal zo groot is als in 1988.

Samenvattend kan gesteld worden dat er geen duidelijk verband wordt aangetroffen tussen persoonlijke kenmerken en de kans op een opleidingsplaats. Het ontbreken van duidelijke factoren die de kans op een opleidingsplaats bevorderen, biedt een verklaring voor het grote aantal basisartsen dat op zoek is naar een opleidingsplaats. Vergeleken met het aantal beschikbare opleidingsplaatsen is het aantal ambitieuze basisartsen immers erg groot. Kennelijk kunnen ook zij - conform de resultaten in tabel 2 - moeilijk inschatten hoe hun kansen liggen, en beschouwen ze de uitkomst van hun zoektocht naar een opleidingsplaats in grote mate als toevallig. Gezien de hoge opbrengst die het verkrijgen van een opleidingsplaats, zeker op lange termijn bezien, oplevert is daardoor voor een grote groep basisartsen het zoeken van een opleidingsplaats de moeite waard. In paragraaf 3 werd een verband gelegd tussen de kans op een opleidingsplaats en de beslissing van basisartsen om zo'n plaats te ambiëren. Verwacht kan worden dat basisartsen die minder kans maken op een opleidingsplaats ook minder snel deze ambitie zullen hebben, omdat de zoekkosten niet zullen opwegen tegen de verwachte baten. Aangezien individuele variabelen geen duidelijk invloed lijken te hebben op de kans om een opleidingsplaats te verwerven, is er bij deze variabelen geen invloed van de realisatiekans op de

5. De onderlinge verschillen tussen de cohortdummy's van de overige jaren zijn niet significant. 
$-13-$

ambitie te verwachten. Echter, de realisatiekans blijkt wel sterk afhankelijk te zijn van het cohort waarin men zich bevindt. Bij de verklaring van de ambitie werd evenwel een veel minder duidelijk verband aangetroffen, en de relatieve grootte van de bijbehorende parameters vertoont weinig overeenkomst met de parameters in tabel 2.

De conclusie kan dus getrokken worden dat de verandering in de kans op een opleidingsplaats, door een wijziging van de algehele arbeidsmarktsituatie, weinig invloed heeft op de ambitie van de basisartsen. Dit wijst erop dat de basisartsen geen goede inschatting kunnen maken van de kansen op een opleidingsplaats en dat daardoor - zelfs zeer significante - veranderingen in deze kansen niet leiden tot verandering van hun gedrag. 


\section{INKOMEN}

De keerzijde van het zoekgedrag van basisartsen bij het allocatieproces op de arbeidsmarkt wordt gevormd door het inkomen dat verbonden is aan de verschillende typen banen. Bij een evenwichtige arbeidsmarkt zullen de banen waarvoor een relatief kleine belangstelling bestaat, ter compensatie een relatief grote beloning kennen. Tabel 4 geeft een beeld van het gemiddelde bruto maandinkomen bij een volledige werkweek, onderscheiden naar de opleidingssituatie waarin basisartsen zich gemiddeld anderhalf jaar na het afstuderen bevinden ${ }^{6}$.

Circa één jaar na het afstuderen bedraagt het bruto maandinkomen bij een volledige werkweek onder betaald werkende basisartsen gemiddeld $f$ 4.375. De inkomensverschillen tussen de respondenten zijn vrij groot (standaardafwijking is $f$ 1.283). De grootste inkomensverschillen doen zich voor onder sociaal-geneeskundigen. Onder huisartsen zijn de verschillen in inkomen het kleinst. Verder komt in tabel 3 naar voren dat sociaal-geneeskundigen het meest verdienen, tenminste gemeten een tot anderhalf jaar na afstuderen.

Tabel 3. Gemiddeld bruto maandinkomen bij een volledige werkweek, naar opleidingssituatie

\begin{tabular}{|c|c|c|c|}
\hline Opleidingssituatie & maandinkomen & standaardafwijking & $\mathrm{n}$ \\
\hline AlO's/OIO's & 2.868 & 1.410 & 19 \\
\hline Specialisten i.o. & $f \quad 4.249$ & 1.268 & 24 \\
\hline Huisartsen i.o. & $f \quad 2.622$ & 564 & 14 \\
\hline Sociaal-geneeskundigen i.o. & $f \quad 5.842$ & 1.576 & 8 \\
\hline AGNIO's & $f \quad 4.747$ & 866 & 110 \\
\hline Anderszins niet in opleiding & $f \quad 4.408$ & 1.255 & 107 \\
\hline Totaal & $f \quad 4.375$ & 1.283 & 282 \\
\hline
\end{tabular}

i.o. $=$ in opleiding

Vanuit de theorie van het menselijk kapitaal kan het volgen van onderwijs worden beschouwd als een investering die later haar rendement oplevert in de vorm van een hoger inkomen. Op grond van deze theorie zouden verschillen in inkomen mogen worden verwacht tussen enerzijds basisartsen die een opleiding volgen (AIO's/OIO's, specialisten in opleiding, huisartsen in opleiding en sociaal-geneeskundigen in opleiding) en anderzijds basisartsen die geen postbasisartsopleiding volgen. Degenen die een opleiding volgen, zouden volgens deze theorie tijdelijk een inkomen accepteren dat lager is dan het inkomen van degenen die geen opleiding volgen. Dit in afwachting van een hoger inkomen na afloop van de opleiding. In het geval van de basisartsen wordt de markt niet alleen opgesplitst in artsen met en artsen zonder een opleidingsplaats, maar ook in artsen met en artsen zonder ambitie voor een dergelijke

6. Voor een toelichting op de berekening van het gemiddelde bruto maandinkomen wordt verwezen naar bijlage 2 . 
opleidingsplaats. Een groot deel van de basisartsen is immers niet in opleiding, maar zoekt wel een opleidingsplaats. Het valt te verwachten dat om zo'n opleidingsplaats te bemachtigen een ambitieuze basisarts strategisch gedrag zal vertonen om zijn kansen te vergroten. Dit strategisch gedrag zal echter niet kosteloos zijn, omdat anders het vergroten van de kans op een opleidingsplaats volledig vrijblijvend zou zijn.

Tabel 4. Gemiddeld bruto maandinkomen bij een volledige werkweek, naar zoekgedrag

\begin{tabular}{|c|c|c|c|c|c|}
\hline \multirow{2}{*}{$\begin{array}{l}\text { Zoekgedrag } \\
\text { Niet ambitieus }\end{array}$} & \multicolumn{2}{|c|}{ maandinkomen } & \multicolumn{2}{|c|}{ standaardafwijking } & \multirow{2}{*}{$\begin{array}{r}n \\
121\end{array}$} \\
\hline & $f$ & 4.386 & $f$ & 1.391 & \\
\hline $\mathrm{AlO} / \mathrm{OIO}$ & $f$ & 2.752 & $f$ & 1.378 & 16 \\
\hline overige & $f$ & 4.634 & $f$ & 1.218 & 105 \\
\hline Nog zoekend & $f$ & 4.500 & $f$ & 983 & 114 \\
\hline In opleiding & $f$ & 4.031 & $f$ & 1.590 & 46 \\
\hline Totaal & $f$ & 4.375 & $f$ & 1.283 & 282 \\
\hline
\end{tabular}

Tabel 4 geeft een overzicht van de lonen van de drie groepen artsen die worden onderscheiden, artsen die geen ambitie voor een opleidingsplaats hebben, zij die nog zoeken en zij die reeds een opleidingsplaats hebben gevonden. De niet ambitieuze groep is opgesplitst in AlO's/OIO's en overige banen. De tabel toont dat de onderlinge loonverhoudingen in overeenstemming zijn met de hierboven geformuleerde theoretische verwachtingen. Afgezien van de AlO's verdienen de artsen zonder ambitie het meest. De artsen die nog op zoek zijn naar een opleidingsplaats leveren $f 134$ per maand in en de artsen in opleiding leveren $f 603$ in ten opzichte van deze groep. De AlO's, wier baan ook een opleidingskarakter heeft, leveren het meeste in ten opzichte van de niet ambitieuzen. Zij verdienen gemiddeld $f 1.882$ minder.

Bij dit soort verschillen kunnen kenmerken tussen beide groepen een rol spelen. Vandaar dat nagegaan wordt welke consequenties de doorstroom naar post-basisarts-onderwijs heeft voor de hoogte van het inkomen. Met behulp van regressie-analyse is gepoogd om variabelen, waaronder het al dan niet volgen van post-basisartsonderwijs, te identificeren die mede een verklaring kunnen vormen voor de hoogte van het bruto maandinkomen bij een volledige werkweek. Als verklarende variabelen voor de hoogte van het inkomen zijn in de regressievergelijking vier achtergrondkenmerken van de respondenten, twee loopbaankenmerken en vijf baankenmerken opgenomen.

De achtergrondkenmerken hebben betrekking op persoonskenmerken (geslacht en leeftijd in het jaar van afstuderen) en extra kwalificaties waarmee men de arbeidsmarkt betreedt (betaalde werkervaring op medisch dan wel niet-medisch gebied, opgedaan vóór of tijdens de studie aan de RL). De twee loopbaankenmerken betreffen het aantal maanden betaalde werkervaring na het afstuderen en het eventueel veranderen van werkgever (externe baanmobiliteit). De geanalyseerde baankenmerken zijn achtereenvolgens: de zekerheid van de baan, de lengte van 
de werkweek, de toeslag voor overwerk, het al dan niet leidinggeven en de opleidingssituatie waarin men terecht is gekomen: $\mathrm{AIO} / \mathrm{OIO}$, huisartsenopleiding, specialistenopleiding, sociaalgeneeskundige of nog zoekend naar een opleidingsplaats. De niet ambitieuze artsen die geen AlO-plaats hebben dienen als referentiegroep ${ }^{7}$. De schattingsresultaten van deze regressievergelijking staan vermeld in tabel $5^{8}$.

Tabel 5. Resultaten regressie-analyse van het bruto maandinkomen van betaald-werkende basisartsen

\begin{tabular}{lcc}
\hline & coëfficiënt & significantie \\
\hline Geslacht (man=1) & $246,1^{*}$ & \\
Leeftijd & 37,2 & 0,09 \\
Medische werkervaring & 175,0 & 0,13 \\
Niet-medische werkervaring & 69,7 & 0,34 \\
Werkervaring na afstuderen & & 0,69 \\
(in maanden) & $24,8^{*}$ & \\
Externe mobiliteit & 210,6 & 0,08 \\
Baanzekerheid & $510,4^{* *}$ & 0,13 \\
Werktijdfactor & 102,2 & 0,01 \\
Inkomenstoeslag & $530,5^{* * *}$ & 0,60 \\
Leiding & 87,7 & 0,00 \\
AlO/OIO & $1645,0^{* * *}$ & 0,57 \\
Huisarts & $-1754,9^{* * *}$ & 0,00 \\
Specialist & $-499,8^{*}$ & 0,00 \\
Sociaal geneesk. & 466,47 & 0,06 \\
Ambitie, nog zoekend & 91,3 & 0,23 \\
Constante & 2617,2 & 0,55 \\
& & 0,00 \\
\hline
\end{tabular}

$\mathbf{R}^{2}=0,35$

Gecorrigeerde $\mathbf{R}^{2}=0,31$

$\mathrm{F}=8,83^{*} *$

* $\quad$ significant op $10 \%$ niveau

* * significant op $5 \%$ niveau

* * significant op $1 \%$ niveau

7. Voor een precieze omschrijving en codering van deze variabelen wordt verwezen naar bijlage 1.

8. Bijlage 3 bevat loonvergelijkingen voor iedere groep afzonderlijk. Met behulp van deze drie afzonderlijke schattingen kan worden nagegaan of de opgenomen achtergrondkenmerken, loopbaankenmerken en baankenmerken een overeenkomstig dan wel verschillend effect hebben op het inkomen van basisartsen die niet naar een opleidingsplaats zoeken (tabel 1 in bijlage 3), basisartsen die nog geen opleidingsplaats hebben gevonden (tabel 2 in bijlage 3) en basisartsen met een opleidingsplaats (tabel 3 in bijlage 3 ).

9. De variabele inkomenstoeslag is opgenomen ter correctie van verschillen in de vraagstelling met betrekking tot het inkomen. In 1991 bevat het gemeten inkomen ook eventuele toeslagen voor overwerk e.d. Voor afstudeerjaar 1991 is een dummy opgenomen, en de bijbehorende coëfficient weerspiegelt derhalve de gemiddelde toeslag op het inkomen. 
De regressiecoëfficiënten in de inkomenstabellen geven in guldens aan hoeveel hoger het bruto maandinkomen is wanneer de desbetreffende dummy-variabele niet de waarde 0 maar de waarde 1 heeft. De regressiecoëfficiënten van de leeftijd en de werkervaring na afstuderen geven aan met hoeveel guldens het bruto maandinkomen toeneemt als de desbetreffende variabelen met een jaar (bij de leeftijd) of een maand (bij de werkervaring na afstuderen) toenemen.

De in de regressievergelijking opgenomen variabelen verklaren gezamenlijk $35 \%$ van de variantie in het inkomen. Eerder is in tabel 3 naar voren gekomen dat sociaal-geneeskundigen in opleiding niet alleen een hoger inkomen verwerven dan basisartsen die andere opleidingen volgen, maar zelfs een hoger inkomen dan basisartsen die geen opleiding volgen, hetzij als AGNIO hetzij anderszins. Aangezien in de schatting de laatste groep als referentiecategorie voor de gevolgde post-basisartsopleiding fungeert, is het niet verwonderlijk dat de parametertekens bij basisartsen die een opleiding volgen (behoudens sociaal-geneeskundigen) negatief zijn.

Conform de theorie van het menselijk kapitaal hebben basisartsen in opleiding een lager inkomen dan basisartsen die geen verdere opleiding volgen, ook wanneer gecorrigeerd wordt voor andere factoren. Sociaal-geneeskundigen in opleiding zijn de enigen die meer verdienen, hoewel niet significant meer. In dit verband dient te worden gewezen op de afwijkende aard van de opleiding voor sociaal-geneeskundige. Zoals eerder opgemerkt wordt deze opleiding namelijk niet 'on the job' gevolgd, zoals bij AIO's/OIO's, huisartsen in opleiding en specialisten in opleiding het geval is, maar wordt zij naast de baan gevolgd.

Naast de gevolgde post-basisartsopleiding varieert de hoogte van het inkomen met de formele duur van de aanstelling en met de toeslag voor overwerk. In vaste dienst verdient men ongeveer $f 500$ bruto per maand meer dan in een tijdelijke baan.

Twee variabelen hebben een effect dat slechts op $10 \%$ niveau significant is, namelijk het geslacht en het aantal maanden betaalde werkervaring na afstuderen. Naar voren komt dat mannen ruim $f 250$ bruto per maand meer verdienen dan vrouwen. Elk jaar werkervaring meer leidt tot een toename van het bruto maandinkomen met zo'n $f 300$. Dit ligt in de orde van grootte van ruim een extra periodiek.

De resultaten van de regressievergelijking bevestigen grotendeels de theoretische ordening van de inkomens van de diverse groepen. Alleen sociaal-geneeskundigen vallen duidelijk buiten dit kader door hun zeer hoge inkomen. Ook blijken basisartsen die op zoek zijn naar een opleidingsplaats, na correctie voor andere variabelen, zelfs enigszins meer te verdienen dan niet ambitieuze artsen (de referentiegroep). Het verschil is evenwel niet significant. Het valt echter te verwachten dat de lagere inkomens van de zoekende artsen, zoals geconstateerd in tabel 4, vooral tot stand komen door een afwijkende selectie van de banen die men kan verkrijgen. Voor een ambitieuze arts is het belangrijker dat een baan zijn kansen vergroot op het verkrijgen van een opleidingsplaats, terwijl voor de niet-ambitieuze groep de beloning een directere rol zal spelen. Daardoor zal niet de beloningsfunctie verschillen, maar zullen de argumenten in de 
$-18-$

beloning door zelfselectie verschillen. Een voorbeeld hiervan is de variabele 'baanzekerheid'. Ambitieuze artsen zullen minder waarde hechten aan een vaste baan, terwijl dit volgens tabel 5 kan leiden tot een inkomensverschil van ongeveer $f 500$. Het blijkt dat inderdaad $18 \%$ van de niet ambitieuze artsen een vaste baan heeft, terwijl dit bij de artsen die op zoek zijn naar een opleidingsplaats slechts $7 \%$ betreft.

De afzonderlijke regressievergelijkingen voor het inkomen per type basisarts lopgenomen in bijlage 3) tonen dat de invloeden op het loon van bepaalde variabelen niet altijd gelijk hoeven te zijn. Bij de niet ambitieuze artsen hebben een vaste baan, leiding geven en externe mobiliteit een grote positieve invloed op het loon. Bij zoekende artsen spelen deze factoren geen grote rol en heeft leiding geven zelfs een negative invloed op het salaris. Voor het salaris van de artsen in opleiding spelen vooral werkervaring (zowel medische als niet-medische) een rol en heeft deeltijdwerk een sterk negatieve invloed. Deze effecten kunnen niet vanzelfsprekend als causaal beschouwd worden. Voor een groot deel zal het hierbij gaan om een selectie van andere achterliggende oorzakelijke factoren.

De loonverschillen tussen de diverse groepen artsen zijn overigens waarschijnlijk te laag om als goede weerspiegeling van de marktverhouding gezien te kunnen worden. $\mathrm{Na}$ anderhalf jaar bedraagt de kans op een opleidingsplaats gemiddeld 29\%. De loonderving van die 18 maanden is volgens tabel $4,18 \times(4634-4500)=f 2412$. Dit betekent dat alleen in geld uitgedrukt de waarde van het verkrijgen van een opleidingsplaats $2412 / 0,29=f 8317$ zou zijn. Daar komt nog bij de loonderving gedurende de opleiding. De waarde van een opleidingsplaats op deze wijze geschat is echter onwaarschijnlijk laag en het valt derhalve te verwachten dat naast de financiele kosten de zeer grote inspanningen die op zoek naar en in de opleidingsplaats gedaan worden, voor een groot deel bijdragen aan de regulering van de toestroom. Een consequentie hiervan is wel dat bij een verlaging van de werkdruk van ambitieuze artsen - die nog op zoek zijn naar een opledingsplaats of reeds in opleiding zijn - de 'kosten' verkleind worden, wat bij een gelijkblijvend salaris voor specialisten zal leiden tot een vergrote belangstelling voor de opleidingsplaats en dus ook tot een verslechterde positie voor ambitieuze artsen, voor zover deze positie wordt afgemeten aan de kans een opleidingsplaats te verwerven. 


\section{SCHETS VAN DE MARKT VOOR MEDISCHE OPLEIDINGSPLAATSEN}

De meeste $(57 \%)$ betaald werkende basisartsen blijken een opleidingsplaats te ambiëren. De kans dat men een opleidingsplaats ambieert neemt toe naarmate men ouder is, en is kleiner wanneer men vóor of tijdens de studie werkervaring op medisch gebied heeft opgedaan. Opvallend is dat naast het geslacht de extra kwalificaties waarover men bij afstuderen beschikt geen significant effect hebben op het al dan niet zoeken naar een opleidingsplaats. Kennelijk spelen human capital argumenten geen rol van betekenis bij de keuze om een postbasisartsopleiding te gaan volgen. Ook de algemene arbeidsmarktsituatie blijkt geen significant effect te hebben op het al dan niet ambiëren van een opleidingsplaats, en daarmee lijken basisartsen niet goed een inschatting van hun kansen op het verkrijgen van een dergelijke opleidingsplaats te kunnen maken.

Van degenen die besloten hebben op zoek te gaan naar een opleidingsplaats is slechts $29 \%$ er circa anderhalf jaar na het afstuderen in geslaagd om een dergelijke plaats te vinden. De kans om een opleidingsplaats te verwerven blijkt niet afhankelijk te zijn van persoonlijke kenmerken als geslacht of leeftijd, noch van extra kwalificaties waarover men beschikt. Dit zou er op kunnen wijzen dat in de medische vakdeelmarkt selectie niet primair geschiedt op basis van het beschikbare human capital, maar dat het basisartsendiploma op zich de belangrijkste factor is, conform de credential-theorie van Collins. De kans om een opleidingsplaats te krijgen blijkt wel zeer sterk afhankelijk te zijn van de algemene arbeidsmarktsituatie waarmee men wordt geconfronteerd.

Conform de theorie van het menselijk kapitaal hebben basisartsen in opleiding een lager inkomen dan basisartsen die geen verdere opleiding volgen, ook wanneer gecorrigeerd wordt voor andere factoren. Sociaal-geneeskundigen in opleiding zijn de enigen die meer verdienen, hoewel niet significant meer. Deze negatieve compensatie vanwege het investeringskarakter van de opleidingsplaats lijkt echter bij lange na niet groot genoeg om vraag en aanbod voor opleidingsplaatsen in evenwicht te krijgen. De verdiensten van de specialismen die volgen op een opleidingsplaats lijken dermate aantrekkelijk te zijn dat een omvangrijke groep basisartsen op zoek blijft gaan naar zo'n opleidingsplaats. Afgezien van de totale beschikbaarheid van opleidingsplaatsen is het moeilijk duidelijk kenmerken aan te geven die de kans op het krijgen van een plaats bepalen. Hierdoor heeft de verdeling van opleidingsplaatsen veel weg van een loterij. Aan weerskanten van de loterij lijkt er sprake te zijn van inefficiëntie. Aan de ene kant lijken de beloningen die wachten nadat men een opleidingsplaats heeft doorlopen veel te hoog, terwijl aan de nadere kant dit aanlokkelijke vooruitzicht leidt tot risicovol zoekgedrag van basisartsen.

Verder blijkt dat artsen die op zoek zijn naar een opleidingsplaats minder verdienen dan hun collega's die deze ambitie niet hebben. Kennelijk maken de zoekende artsen strategische keuzen die hun kans op een opleidingsplaats vergroten, maar hun inkomen verkleinen.

De geconstateerde loonverschillen kunnen echter niet volledig de marksituatie verklaren. Gezien 
de aantrekkelijkheid van een opleidingsplaats zouden de salarisopofferingen van zoekende artsen veel groter moeten zijn. Deze opofferingen worden waarschijnlijk vooral gemaakt op het vlak van de inspanningen die de zoekende artsen en de artsen in opleiding moeten verrichten.

Zolang opleidingsplaatsen toegang blijven verschaffen tot banen die structureel overgewaardeerd worden, zal er een grote groep basisartsen blijven bestaan die langdurig op zoek zijn naar zo'n opleidingsplaats. Het heeft onder die omstandigheden niet veel zin om de zware werklast van de ambitieuze artsen te verkleinen, omdat dit alleen zal leiden tot een nog grotere belangstelling voor de opleidingsplaatsen. Hierdoor zullen de kansen op een opleidingsplaats alleen maar kleiner worden.

Gezien het bijzondere karakter van de arbeidsmarkt voor artsen is het interessant de problematiek die geschetst werd in dit paper ook in de toekomst verder te onderzoeken. Ten eerste zal het gebruikte meetinstrument, de RL-scanner, over enige tijd ook informatie verschaffen over de verdere loopbaan van artsen. Dit levert ook verdere informatie op over de beloning en het arbeidsmarktgedrag van de artsen gedurende de looptijd van hun opleiding en daarna. Op basis van deze data kan nader inzicht verkregen worden over het functioneren van de arbeidsmarkt van medici. Ten tweede zijn de resultaten van dit paper gebaseerd op een indirecte meting van de ambitie van artsen. Het zou interessant zijn middels directe vragen naar de plannen en doelstellingen van basisartsen, ook de beleving van artsen zelf in het onderzoek te betrekken. 


\section{LITERATUUR}

Collins, R. (1979), The Credential Society. New York.

Goddeeris, J.H. (1988), 'Compensating Differentials and Self-Selection: An Application to Lawyers'. Journal of Political Economy 96, pp. 411-428.

Hartog, J. (1992), Capabilities, Allocation and Earnings. Boston.

Hoof, G. van, A. Knepper, A. de Leeuw, R. Neefjes, en J. Schmitz (1992), Basisarts: dokteren aan je toekomst. VU Amsterdam.

Manski, C. (1989), 'Schooling as Experimentation: A Reappraisal of the Postsecondary Dropout Phenomenon'. Economics of Education Review 8, pp. 305-311.

Ramaekers, G.W.M. en J.A.M. Heijke (1991), Arbeidsmarktscanner Rijksuniversiteit Limburg. Afgestudeerden 1986 - 1989. ROA-R-1991/6.

Willis, R.J., and S. Rosen (1979), 'Education and Selfselection'. Journal of Political Economy 87 Suppl., pp. 7-36. 


\section{BIJLAGE 1. DEFINITIE VAN VARIABELEN IN DE SCHATTINGEN}

\section{Te verklaren variabelen}

Ambitie

0 is niet op zoek naar een medische opleidingsplaats

1 werkt in een medische opleidingsplaats of is op zoek naar een medische opleidingsplaats

\section{Realisatie}

0 is op zoek naar een medische opleidingsplaats

1 werkt in een medische opleidingsplaats

Bruto maandinkomen (zie bijlage 2)

\section{Verklarende variabelen}

Geslacht

0 vrouw

1 man

Leeftijd

leeftijd in jaren op moment van afstuderen

HO-vooropleiding

0 beschikt niet over HBO- of WO-diploma voor aanvang van RL-studie

1 beschikt wel over HBO- of WO-diploma voor aanvang van RL-studie

\section{Studentassistent}

0 geen studentassistentschap verricht

1 wel studentassistentschap verricht

Medische werkervaring

0 geen betaalde werkervaring op medisch gebied, opgedaan vóor afstuderen

1 wel betaalde werkervaring op medisch gebied, opgedaan vóór afstuderen

Niet-medische werkervaring

0 geen betaalde werkervaring op niet-medisch gebied, opgedaan vóór afstuderen

1 wel betaalde werkervaring op niet-medisch gebied, opgedaan vóór afstuderen

Bestuurlijke ervaring

0 geen bestuurlijke ervaring opgedaan vóor afstuderen

1 wel bestuurlijke ervaring opgedaan vóor afstuderen 


\section{Cohort ' 88}

0 in 1989, 1990 of 1991 afgestudeerd

1 in 1988 afgestudeerd

\section{Cohort ' 89}

0 in 1988, 1990 of 1991 afgestudeerd

1 in 1989 afgestudeerd

\section{Cohort '90}

0 in 1988,1989 of 1991 afgestudeerd

1 in 1990 afgestudeerd

\section{Cohort '91}

0 in 1988, 1989 of 1990 afgestudeerd

1 in 1991 afgestudeerd

\section{Zoektijd}

Aantal maanden dat men reeds is afgestudeerd

\section{Werkervaring na afstuderen}

Aantal maanden betaalde werkervaring, opgedaan na het afstuderen

Externe mobiliteit

0 niet van werkgever veranderd

1 wel van werkgever veranderd

\section{Baanzekerheid}

0 tijdelijke aanstelling ( $<61$ maanden)

1 vaste aanstelling ( $>60$ maanden)

\section{Werktijdfactor}

0 part-time baan ( $<35$ uur per week)

1 full-time baan ( $>34$ uur per week)

Inkomenstoeslag

0 vóór 1991 afgestudeerd

1 in 1991 afgestudeerd

Leidinggeven

0 geen leidinggevende functie

1 wel leidinggevende functie 


\section{$\mathrm{AlO} / \mathrm{OIO}$}

0 werkt niet als $\mathrm{AlO} / \mathrm{OIO}$

1 werkt wel als $\mathrm{AlO} / \mathrm{OIO}$

Sociaal-geneeskundige i.o.

0 werkt niet als sociaal-geneeskundige in opleiding

1 werkt wel als sociaal-geneeskundige in opleiding

Huisarts i.o.

0 werkt niet als huisarts in opleiding

1 werkt wel als huisarts in opleiding

Medisch specialist i.o.

0 werkt niet als medisch specialist in opleiding

1 werkt wel als medisch specialist in opleiding

AGNIO

0 werkt niet als AGNIO

1 werkt wel als AGNIO 


\section{BIJLAGE 2. BEREKENING VAN HET INKOMEN}

\section{Afstudeercohorten '88, '89 en '90}

Bij de afstudeercohorten ' 88 , ' 89 en '90 is aan degenen die een betaalde functie uitoefenen, gevraagd naar de hoogte van het bruto inkomen per maand bij een volledige werkweek (exclusief toeslagen voor overwerk, dertiende maand, vakantiegeld en dergelijke). In de basisvragenlijsten voor deze cohorten zijn de volgende 9 inkomensklassen onderscheiden, waarvan de laagste en de hoogste 'open' zijn:

$1=<f 1500 ; 2=f 1500-f 2000 ; 3=f 2000-f 2500 ; 4=f 2500-f 3000 ; 5=$

$f 3000-f 3750 ; 6=f 3750-f 5000 ; 7=f 5000-f 7500 ; 8=f 7500-f 12500 ; 9=$ $f 12.500$ of meer.

Teneinde een inkomenswaarde te kunnen berekenen, is aan de waarnemingen die vallen binnen de zeven 'gesloten' inkomensklassen de waarde toegekend van het desbetreffende klassenmidden. Bij de waarnemingen die vallen in de hoogste ('open') inkomensklasse is de laagste waarde gebruikt: $f$ 12.500. Bij de laagste ('open') inkomensklasse is de hoogste waarde gebruikt, die $f$ 1500 bruto per maand bedraagt. Dit komt ongeveer neer op het wettelijk minimumloon in de periode 1989-1991. Het voorgaande betekent dat het bruto maandinkomen van de cohorten ' 88 , ' 89 en '90 de volgende acht waarden kan aannemen:

$f 1.500 f 1.750$ f 2.250 f 2.750 f $3.375+4.375$ f $6.250 f 10.000 f 12.500$

Bij afstudeercohort ' 90 is aan de betaald werkende afgestudeerden daarnaast gevraagd om de hoogte van het bruto maandinkomen bij een volledige werkweek exact aan te geven (exclusief toeslagen voor overwerk, dertiende maand, vakantiegeld en dergelijke). Bij degenen die het inkomen exact hebben aangegeven, is het exact aangeven inkomen gebruikt.

\section{Afstudeercohort'91}

Teneinde de vraag naar het inkomen beter af te stemmen op de door het CBS gehanteerde vraagstelling, is voor het eerst bij afstudeercohort ' 91 achtereenvolgens gevraagd naar:

1 het totale bruto maandinkomen (excl. vakantiegeld), waarbij men een eventuele $13 \mathrm{e}$ maand of jaargratificatie voor een twaalfde deel moet meerekenen;

2 het deel van het totale bruto maandinkomen dat bestaat uit eventuele toeslagen voor overwerk, onregelmatig werk, ploegendienst e.d.

Het in de schatting gebruikte inkomen van afstudeercohort '91 is berekend door het totale bruto maandinkomen eerst te delen door het aantal uren dat men contractueel werkt, en vervolgens te vermienigvuldigen met 40 . Het aldus berekende gemiddelde bruto maandinkomen van afstudeercohort '91 kwam weliswaar het dichtst bij het gemiddelde bruto maandinkomen van degenen die in de periode 1988-1990 zijn afgestudeerd, maar lag nog altijd $f 710$ hoger. Vandaar dat in de schattingen van het inkomen een 'toeslagdummy' is opgenomen. Deze heeft de waarde 0 indien men vóór 
$-26-$

\section{BIJLAGE 3. SCHATTINGSRESULTATEN VAN HET INKOMEN}

Tabel 1. Resultaten regressie-analyse van het bruto maandinkomen van basisartsen die niet op zoek zijn naar een opleidingsplaats

regressiecoëfficiënt significantie

$\begin{array}{lcc}\text { Geslacht } & 280,6 & 0,25 \\ \text { Leeftijd } & 72,6 & 0,12 \\ \text { Medische werkervaring } & 195,5 & 0,47 \\ \text { Niet-medische werkervaring } & 3,9 & 0,99 \\ & & \\ \text { Werkervaring na afstuderen } & 0,2 & 0,99 \\ \text { (in maanden) } & 442,1^{*} & 0,06 \\ \text { Externe mobiliteit } & 886,5^{* * *} & 0,01 \\ \text { Baanzekerheid } & -116,3^{*} & 0,73 \\ \text { Werktijdfactor } & 415,6 & 0,10 \\ \text { Inkomenstoeslag } & 616,9^{* *} & 0,02 \\ \text { Leiding } & 1362,3^{* * *} & 0,00 \\ \text { AIO/OIO } & 497,2^{*} & 0,08 \\ \text { AGNIO } & 1674,3 & 0,16 \\ \text { Constante } & & \end{array}$

Gecorrigeerde $R^{2}=0,35$

$F=6,30 * *$

* $\quad$ significant op $10 \%$ niveau

* * significant op $5 \%$ niveau

* * $\quad$ significant op $1 \%$ niveau 
Tabel 2. Resultaten regressie-analyse van het bruto maandinkomen van basisartsen die vergeefs op zoek zijn naar een opleidingsplaats

regressiecoëfficiënt

$\begin{array}{rr}258,4 & 0,22 \\ 24,1 & 0,48 \\ -67,0 & 0,81 \\ -59,7 & 0,82\end{array}$

Werkervaring na afstuderen

(in maanden)

Externe mobiliteit

Baanzekerheid

Werktijdfactor

Inkomenstoeslag

Leiding

AlO/OIO

AGNIO

Constante

$\begin{array}{rr}29,6 & 0,14 \\ 22,7 & 0,91 \\ 606,4 & 0,14 \\ 271,8 & 0,29 \\ 438,2 & 0,10 \\ -368,0 & 0,10 \\ -1010,6 & 0,11 \\ 131,4 & 0,57 \\ 3070,3 \text { * * } & 0,00\end{array}$

significantie
0,81

0,82

0,14

0,29

0,10

11

0,00

Gecorrigeerde $\mathbf{R}^{2}=0,11$

$F=2,04$ *

* $\quad$ significant op $10 \%$ niveau

* * significant op 5\% niveau

* * significant op $1 \%$ niveau 
$-28-$

Tabel 3. Resultaten regressie-analyse van het bruto maandinkomen van basisartsen die een opleidingsplaats hebben gevonden

\begin{tabular}{lcc}
\hline & regressiecoëfficiënt & significantie \\
\hline Geslacht & $-109,2$ & 0,80 \\
Leeftijd & $-28,0$ & 0,71 \\
Medische werkervaring & $1130,5^{*}$ & 0,07 \\
Niet-medische werkervaring & $865,2^{*}$ & 0,07 \\
Werkervaring na afstuderen & & \\
(in maanden) & $92,2^{* *}$ & 0,03 \\
Externe mobiliteit & $-572,2$ & 0,16 \\
Werktijdfactor & $-1301,0^{*}$ & 0,06 \\
Inkomenstoeslag & 467,5 & 0,29 \\
Leiding & 59,8 & 0,90 \\
Huisarts & $-1704,1^{* *}$ & 0,02 \\
Specialist & $-816,5$ & 0,11 \\
Constante & $5278,8^{* *}$ & 0,04 \\
\hline
\end{tabular}

Gecorrigeerde $\mathbf{R}^{2}=0,52$

$F=5,23^{* * *}$

* significant op $10 \%$ niveau

* * significant op $5 \%$ niveau

* * significant op $1 \%$ niveau 